\title{
The Role of Job Satisfaction in Mediating the Effect of Work Stress and Democratic Leadership on Employee Performance at Sushimi Restaurant in Bali
}

\author{
Ni Putu Ayu Tika Kurniawati ${ }^{1}$, Ida Bagus Udayana Putra², I Made Suniastha Amerta ${ }^{3}$ \\ Master of Management, Warmadewa University Postgraduate Program \\ tikakurniawati1991@gmail.com
}

\begin{tabular}{|l|}
\hline Published: 19/03/2021 \\
\hline How to cite (in APA style): \\
Kurniawati, N., Putra, I., \& Amerta, I. (2021). The Role of Job Satisfaction in Mediating the Effect of Work \\
Stress and Democratic Leadership on Employee Performance at Sushimi Restaurant in Bali. Jurnal \\
Ekonomi dan Bisnis Jagaditha, Vol. 8 (1), 90-93. doi: http://doi.org/10.22225/jj.8.1.3130.90-93
\end{tabular}

\begin{abstract}
Employee performance is very important in managing a company. Performance is the result of the quality and quantity of work achieved by an employee in carrying out his duties according to the responsibilities assigned to them. Therefore, to be able to improve the performance of company employees, it is necessary to pay attention to the factors that affect performance. This study aims to determine the role of Job Satisfaction in mediating the effect of Job Stress and Democratic Leadership on Employee Performance at the Sushimi Bali Restaurant. The population in this study were all employees at the Sushimi Bali restaurant. The method used in this research is descriptive analysis method and inferential analysis using the Smart PLS (Partial Least Square) programs. The results showed that: (1) job stress has a negative and significant effect on employee performance, (2) job stress has a negative and significant effect on job satisfaction, (3) democratic leadership has a positive and significant effect on employee performance, (4) democratic leadership has a significant effect. positive and significant impact on job satisfaction, (5) job satisfaction has a positive and significant effect on employee performance, (6) job satisfaction does not mediate the relationship between job stress and employee performance, (7) job satisfaction does not mediate the relationship between democratic leadership and employee performance. It is suggested to the next researchers if they are going to conduct research on employee performance, they can take other variables besides job stress, democratic leadership and job satisfaction.
\end{abstract}

Keywords: Employee Performance, Job Satisfaction, Work Environment, Work Motivation

\section{INTRODUCTION}

Human resources are the most important asset in a company because of its role as the subject of the implementation of the company's operational activities. Because the role of human resources is increasingly important in achieving the company's goals, it needs to be improved in order to obtain quality human resources. According to Mangkunegara (2009), human resources (HR) is a planning, organizing, coordinating, implementation and supervision of procurement, development of reciproation, integration, maintenance and separation of labor in order to achieve the objectives of the organization.
The restaurant business in Bali today can be quite promising. Restaurant is a business of providing food and beverage services equipped with equipment and equipment for the process of making, storing and serving in a fixed place and not moving around with the aim of obtaining profit. The purpose of the operation of the restaurant itself is to make a profit and make satisfied its customers. International restaurants can be found easily along the tourist area in Bali, one of which is Sushimi Bali located at Jalan Camplung Tanduk no. 4x, Seminyak, Bali.

The phenomenon that occurs in Sushimi restaurant in Bali lies in the performance of employees who are not maximal. The triggering of the problem after making initial observations 
can be seen from employees who often daydream while at work because of the pressures and workload felt by employees and leaders who seem fierce so that employees become less comfortable while working. Through field observations, it was informed that the attendance rate of employees at Sushimi Bali restaurant in 2019 was quite high. Many employees reasoned not to come during their working hours resulting in a decrease in employee performance. Related to the job satisfaction as a main object in this research, there are plenty of researches that had been carried out previously such as Ahmed \& Ramzan (2013); Bashir \& Ramay (2010); Carmeli \& Freund (2004); Dharmanegara, Sitiari, \& Wirayudha (2016); Jusmin, Said, Bima, \& Alam (2016); Kardiasih, Yasa, \& Sitiari (2017); Martini \& Widyani (2019). Thus, this current research was conducted by the purpose of determining the role of Job Satisfaction in mediating the effect of Job Stress and Democratic Leadership on Employee Performance at the Sushimi Bali Restaurant.

\section{METHOD}

This research was conducted by employing a qualitative reserach method. The data source of this research is the withdrawal of primary data on variables of work stress, democratic leadership, employee performance and job satisfaction using questionnaires, where the data obtained is qualitative. According to Sugiyono (2016:86), the likert scale is used to measure attitudes, opinions and perceptions or a group of people about social phenomena. Each questionnaire answer has a weight or score of values with a likert scale that is 1 to 5 where $1=$ Strongly Disagree, 2 = Disagree, $3=$ Undecided, $4=$ Agree, $5=$ Strongly Agree based on their perception of work stress.

Some of the methods used are interviews, namely data collection techniques carried out by conducting direct questioning both to agency leaders mapun conducted with employees to obtain the necessary information about work stress, democratic leadership, employee performance and job satisfaction by looking at attendance and employee performance conditions. Questionnaire is a data collection technique by providing prepared statements in advance in the form of statements filled out by direct respondents.

While the data analysis method used is descriptive analysis, which is an analysis done to assess the characteristics of a data. Descriptive analysis used in this study is to describe the characteristics of research respondents judging from several research variables related to respondents' perception of work stress, democratic leadership, employee performance and job satisfaction. There is also inferential analysis, which is used to analyze the relationships between variables in this study, including work stress, democratic leadership, job satisfaction and employee performance. In analyzing the influence between exogenous variables and endogenous variables in this study used the statistical method Partial Least Square (PLS). Therefore this method is known to be very practical and does not require many assumptions including normal distribution assumptions. According to (Jogiyanto \& Abdillah, 2009), PLS (Partial Least Square) is a variant-based structural equation modeling (SEM) analysis that can simultaneously test measurement models as well as structural model testing. Measurement models are used for validity and reliability tests, while structural models are used for causality tests (hypothesis testing with prediction models).

\section{RESULTS}

Respondents in this study were dominated by male respondents of 18 people or 53 percent. Based on age, respondents in this study were the most likely to be aged 21-30 years, amounting to 26 people or 76 percent, of which age is classified as productive age. With the sense, in the age range of 21-30 years is still able to work to the maximum both in terms of energy and dexterity in work, so that the company with a more dominated workforce with a productive age is expected to achieve maximum performance. Then based on the length of work, dominated by respondents who have worked for an average of 1-5 years, which amounts to 22 people or 65 percent. When validity and reliability tests are performed, the results also show that all indicators show valid and reliable values.

In the use of descriptive analysis, using variable descriptions of work stress, democratic leadership, job satisfaction and employee performance. Results showed that overall on work stress variables obtained an average score score of 2.09 with low criteria measured on employees of Sushimi restaurants in Bali. In democratic leadership variables obtained an average score of 3.76 with high criteria. The 
largest assessment related to democratic leadership is on the indicator of prioritizing cooperation in achieving the company's goals with an average score of 3.79 and the lowest value on the indicator that is appreciating each potential owned by employees with an average score of 3.74. While the average score of job satisfaction variables with eight indicators as a measurement has a value of 3.82 with high criteria. For employee performance value variable average value with eight indicators as the measurement has a value of 3.58 with high criteria.

Using inferential analysis, convergent validity testing showed that the entire outer loading value of the variable indicator has a value greater than 0.50 with a $\mathrm{p}$ value of 0.000 less than 0.05 . Thus, it can be concluded that all indicators have met convergent validity requirements. work stress directly affects the performance of employees with a coefficient of -0.264 , democratic leadership directly affects the performance of employees with a coefficient of 0.447 . Work stress has a direct effect on job satisfaction with a coefficient of -0.620 . Democratic leadership has a direct effect on job satisfaction with a coefficient of 0.432 . Job satisfaction directly affects employee performance with a coefficient of 0.307 . Using composite reliability and Cronbach alpha, the composite reliability and cronbach alpha values of each construct are, job stress, democratic leadership, job satisfaction, and employee performance are all above 0.70 . Thus, it can be explained that the entire construct meets the reliabel requirements.

\section{DISCUSSION}

Work stress has a negative and significant influence on employee performance. The higher the level of work stress in employees, the significantly lower the performance of those employees. This can be seen from the test results that work stress negatively affects -0.264 on performance, and the relationship is significant because the statistical tilapia is greater than 1.96 which is 1,973 . Work stress is measured by several indicators, namely psychological indicators such as feeling restless and restless for some reason, physical indicators that are feeling tired and tired due to work and workload, and behavioral indicators that are avoiding work or delaying work. Based on the results of employee research at Sushimi Bali restaurant, employees' work stress is relatively low, the highest score can be seen from the indicator of feeling tired and tired in getting the job done. Workload and pressure on work often make employees physically stressed, namely tired and tired in doing work during working hours. Work stress also has a negative and significant influence on job satisfaction. The higher the employee's work stress level, the lower the job satisfaction felt by the employee. This can be seen from the test results that showed that work stress negatively affects job satisfaction of -0.620 , and the relationship is significant because the t-statistical value is greater than 1.96 which is 5,342. Indicators that support job satisfaction are the amount of salary given to employees, the opportunity of employees to progress in the organization (promotion), the supervision of the supervisor (leadership), cooperative colleagues, satisfied with the work that has been completed, acting voluntarily in helping others without expecting rewards, the status of work obtained by working hard, and a good work environment within the company. Based on the results of the analysis we can see that the work stress experienced by employees at Sushimi Bali restaurant can affect what they feel whether it concerns work or the results they receive.

While democratic leadership has a positive and significant effect on employee performance. democratic leaders will significantly improve the performance of employees at Sushimi restaurants in Bali. This can be seen from the test results that showed that democratic leadership had a positive effect of 0.447 on performance and the relationship was significant because the $t$-statistical value was greater than 1.96 which was 2,982 . Democratic leadership is measured by several indicators including the ability of leaders in making decisions, the ability of leaders in motivating their employees, the ability to communicate with employees, the ability to control subordinates, responsible leaders, and the ability of leaders in controlling their emotions.

In this research the leadership in Sushimi restaurant in Bali has been good. This can be seen from the fact in the field that democratic leadership has a positive impact, especially the attitude of leaders who prioritize teamwork. Leaders who prioritize cooperation in achieving the goals of Sushimi Bali restaurants tend to improve employee performance and make employees work as well as possible. In addition, 
several other factors such as the ability of leaders in making decisions, the ability to communicate, the ability to control their emotions, and responsible decision making are some of the other factors appreciated by employees. But in terms of motivating their employees to give the lowest value, employees give the view that leaders should be able to appreciate the potential of employees and can motivate each employee so that employees can further improve performance so as to achieve more maximum results. Democratic leadership has a positive and significant effect on job satisfaction, the better the leader in leading the company, the more satisfied employees are in working at Sushimi restaurants in Bali. This can be seen from the results of the hypothesis that democratic leadership has a positive effect of 0.432 on job satisfaction and the relationship is significant because the t-statistical value is greater than 1.96 which is 4,021. Good leadership tends to give employees satisfaction. In this study, employees at Sushimi Bali restaurant were satisfied with the leader who prioritized cooperation in achieving the company's goals.

Job satisfaction in sushimi bali restaurant employees also has a positive effect, but not significantly on employee performance, the more satisfied employees in their work, the more performance will increase but the association is not significant. This can be seen from the results of the hypothesis that job satisfaction has a positive effect of 0.307 on employee performance, but the relationship is not significant because the t-statistical value is less than 1.96 which is 1,703 . In this study, job satisfaction in sushimi restaurant employees in Bali was good. This can be seen from the fact in the field that employees are satisfied with the work they are doing at the moment. Employees at Sushimi Bali restaurants tend to have been satisfied with the current job that is in accordance with their respective Job Desks so that the performance of the employees is more maximal.

\section{CONCLUSION}

The effect of work stress on employee performance is not mediated by job satisfaction at Sushimi restaurant in Bali. This means that job satisfaction is not able to explain the effect of work stress on employee performance, and the influence of democratic leadership on employee performance is not mediated by job satisfaction. This means that job satisfaction is not able to explain the influence of democratic leadership on employee performance.

\section{REFERENCES}

Ahmed, A., \& Ramzan, M. (2013). Effects of Job Stress on Employees Job Performance: A Study on Banking Sector of Pakistan. IOSR Journal of Business and Management, 11(6), 61-68.

Bashir, U., \& Ramay, M. I. (2010). Impact of Stress on Employees Job Performance: A Study on Banking Sector of Pakistan. International Journal of Marketing Studies, 2(1), 122-126.

Carmeli, A., \& Freund, A. (2004). Work Commitment, Job Satisfaction, and Job Performance: An Empirical Investigation. International Journal of Organization Theory and Behavior, 6(4), 289-309.

Dharmanegara, I. B. A., Sitiari, N. W., \& Wirayudha2, I. D. G. N. (2016). Job Competency and Work Environment: The effect on Job Satisfaction and Job Performance among SMEs Worker. IOSR Journal of Business and Management (IOSR-JBM), 18(1), 19-26.

Jogiyanto, \& Abdillah, W. (2009). Konsep dan Aplikasi PLS (Partial Least Square) untuk Penelitian Empiris. Yogyakarta: BPFE.

Jusmin, A., Said, S., Bima, M. J., \& Alam, R. (2016). Specific Determinants of Work Motivation, Competence, Organizational Climate, Job Satisfaction and Individual Performance: A Study among Lecturers. Journal of Business and Management Sciences, 4(3), 53-59.

Kardiasih, K., Yasa, S., \& Sitiari, W. (2017). Pengaruh Motivasi dan Lingkungan Kerja Fisik terhadap Kepuasan Kerja dan Kinerja Pegawai pada Dinas Kebudayaan Kota Denpasar. Jurnal Ekonomi Dan Bisnis JAGADITHA, 4(2), 5562.

Mangkunegara, A. . A. P. (2009). Manajemen Sumber Daya Manusia Perusahaan. Bandung: PT. Remaja Rosdakarya.

Martini, L. K. B., \& Widyani, A. A. D. (2019). Effects of Empowerment, Work Climate and Job Satisfaction on Employee Performance of Transportation Office of Klungkung Regency. Jurnal Ekonomi Dan Bisnis JAGADITHA, 6(2), 99-103.

Sugiyono. (2016). Metode Penelitian Kombinasi (Mixed Methods). (M. Sutopo, Ed.). Bandung: CV. Alfabeta. 